\title{
2018 年度精密工学会論文賞・沼田記念論文賞・高城賞・研究奨励賞業績の紹介
}

\author{
2018 年度（第 15 回）精密工学会論文賞
}

微小多極着磁磁石を用いた 2 自由度マイクロ電磁アクチュエータの試作

精密工学会誌 84 卷 3 号, pp. 289-294

2 自由度電磁アクチュエータの原理の創出, それを具体化する MEMS 技術を用いた多層コイル構造や磁気回路構成のデ ザイン，これらを具現化するためのレーザ加工や放電加工などを含む加工プロセスの構築，そして試作と試作品の評価を 行っている. 本研究は新規性, 進歩性, 独自性が高く, また, 産業上の利用価值の高さも期待できる. ものづくりのプロ セスのすべてを含み，技術革新の規範となる研究論文であることを高く評価した。

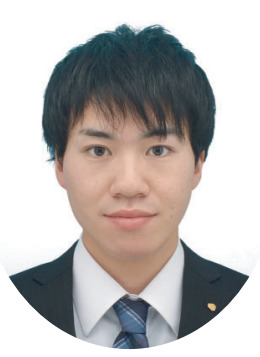

吾 妻 範 栄

2018 年東京工業大学 工学院機械系機械コー

又修士課程修了。

TDK 株式会社. 修士 (工学)

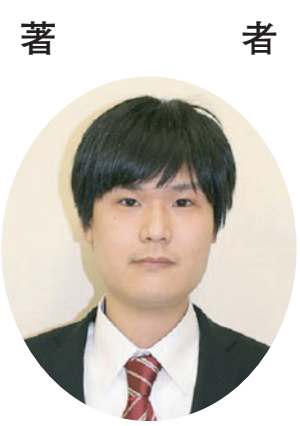

田中俊也

2017 年東京工業大学 大学院総合理工学研究 科メカノマイクロ工学 専攻修士課程修了。 JX 金属株式会社。修 士 (工学)

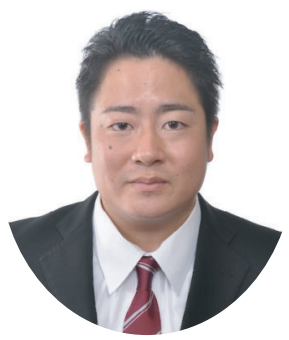

藤 原 良 元

2016 年東京工業大学 大学院総合理工学研究 科メカノマイクロ工学 専攻博士課程修了。 TDK 株式会社. 博士 (工学)

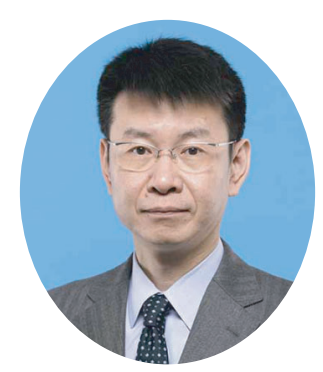

進 士 忠 彦

1992 年東京工業大学 大学院総合理工学研究 科精密機械システム専 攻修士課程修了。東京 工業大学科学技術創成 研究院未来産業技術研 究所教授. 博士（工

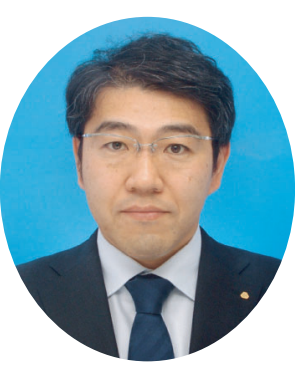

鈴 木 健 一

2007 年長岡技術科学 大学大学院工学研究科 材料工学専攻博士課程 修了。 T DK 株式会 社. 博士 (工学) 
実験とシミュレーションによる砥粒径のばらつきがウエハ研削面に与える影響の調査

精密工学会誌 84 巻 7 号, pp. 640-645

本論文は，これまでほとんど注目されていなかった砥粒径のばらつきに着目し，分級の度合いが高いほど仕上面粗さや 加工能率が向上することを，理論ならびにシミュレーションにより明らかにした，さらに研削実験により定量的に一致す ることを示した，この結果は工学的に有用であるとともに，砥石の製造指針を与える技術として工業的実用性も非常に高 い.よって精密工学の発展に寄与すると認められ, 論文賞にふさわしいと判断した.

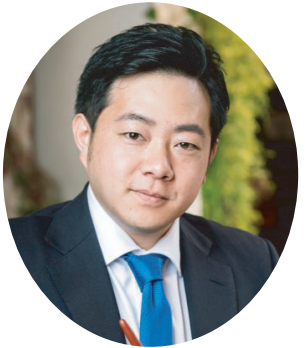

蛯 名 雄太郎

2017 年茨城大学大学 院理工学研究科博士後 期課程生産科学専攻単 位取得满期退学. 茨城 県国体・障害者スポー ツ大会局総務企画課. 修士（工学）
著

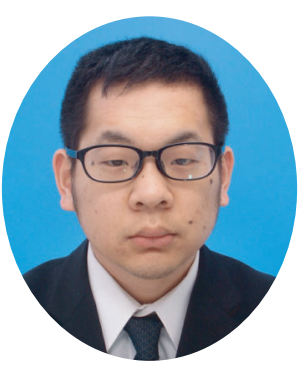

前 崎 智 博

2019 年茨城大学大学 院理工学研究科博士前 期課程知能システム工 学専攻修了 (予定) 。 茨城大学大学院理工学 研究科博士前期課程 2 年 生. 修士 (工 学) (予定)

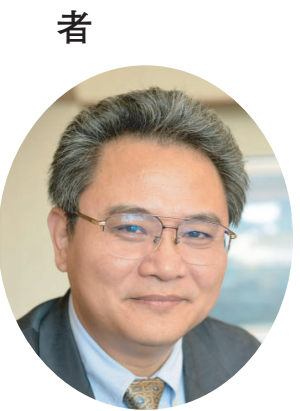

周

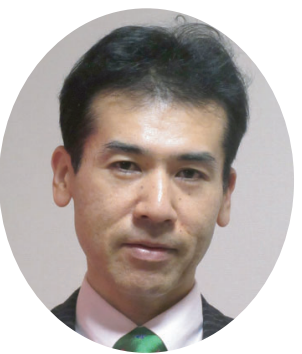

清 水
1991 年東北大学大学 院工学研究科博士後期 課程精密工学専攻修 了. 茨城大学大学院理 工学研究科機械システ 厶工学専攻教授. 工学 博士

1997 年茨城大学大学 院工学研究科博士後期 課程生産科学専攻修 了. 茨城大学大学院理 工学研究科機械システ 公工学専攻教授. 博士 (工学)

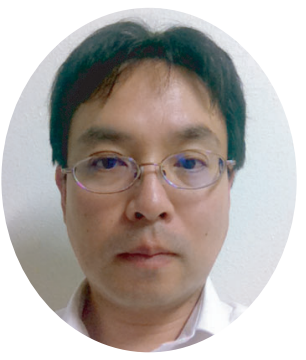

小貫 哲 平

2003 年東京理科大学 大学院基礎工学研究科 博士後期課程材料工学 専攻修了。茨城大学大 学院理工学研究科機械 システム工学専攻准教 授. 博士 (工学)

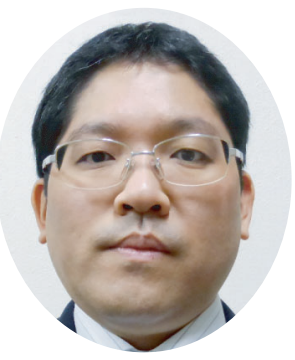

尾 嶌 裕 隆

2004 年名古屋大学大 学院工学研究科博士後 期課程電子機械工学専 攻修了. 茨城大学大学 院理工学研究科機械シ ステム工学専攻准教 授. 博士 (工学)

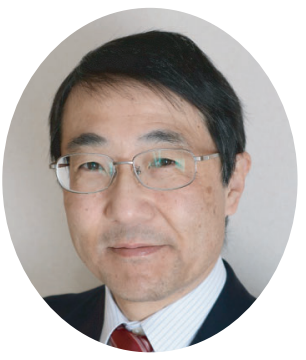

乾 正 知

1988 年東京大学大学 院工学系研究科情報工 学専攻博士課程中途退 学. 茨城大学大学院理 工学研究科機械システ 厶工学専攻教授. 工学 博士 
One-shot stereolithography for biomimetic micro hemisphere covered with relief structure

Precision Engineering Vol. 54, pp. 353-360

本論文は生体模倣表面, 特に微小突起がついた数十 $\mu \mathrm{m}$ の半球形状を 1 回の露光で作製する新手法を提案し, 実際に試 作した。液浸光学系で高屈折率側から低屈折率側のレジストを感光させる工夫により，レジスト層への出射角が浅くなり， 半球の製作を可能にした。この手法は半球以外の 2 重スケール構造にも適用できる沉用性があるので今後の応用研究にも 期待できる。この成果は工学的・工業的な有用性が高く, 精密工学の進展に大きく寄与するものと認められる.

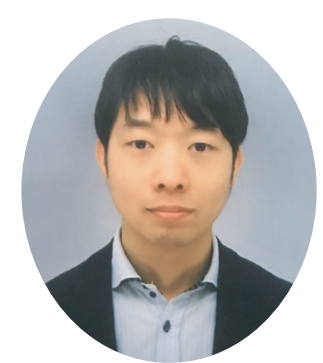

鈴 木 裕 貴

2017 年東京大学大学 院工学系研究科精密工 学専攻修士課程修了. JXTGエネルギー株式 会社. 修士（工学）

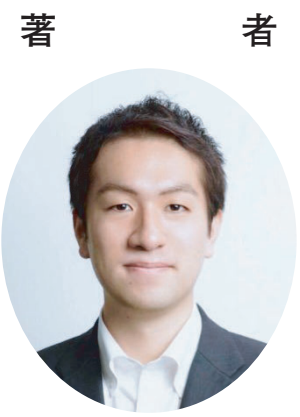

鈴 木 邦 和

2016 年東京大学工学 部精密工学科卒業. 東 京都議会議員 $(1$ 期). 学士 (学)

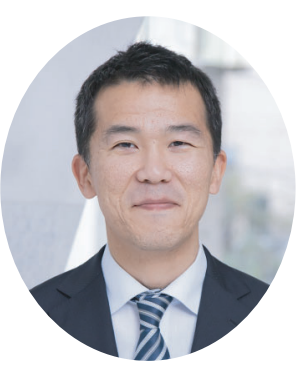

道畑正岐

2010 年大阪大学大学 院工学研究科機械工学 専攻博士後期課程修 了。東京大学先端科学 技術研究センター助 教. 博士 (工学)

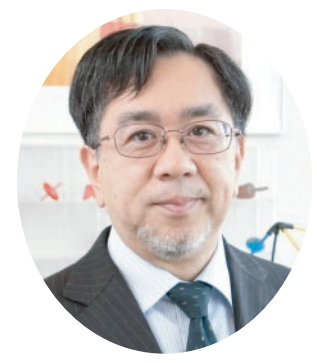

高 増 潔

1982 年東京大学大学 院工学系研究科精密機 械工学専攻博士課程修 了. 東京大学大学院工 学系研究科精密工学専 攻教授. 工学博士

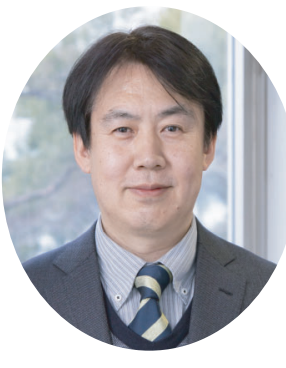

高 橋 哲

1995 年大阪大学大学 院工学研究科産業機械 工学専攻博士前期課程 修了. 東京大学先端科 学技術研究センター教 授. 博士 (工学) 


\section{8 年度（第 35 回）精密工学会沼田記念論文賞}

Sensor-less on-line chatter detection in turning process based on phase monitoring using power factor theory

Precision Engineering Vol. 51, pp. 103-116

本論文は, 切削力と工具変位／速度関係の位相差を表す機械的エネルギー係数およびパワー係数を導入し，旋削加工の ためのセンサーレス・オンライン・チャタリング検出法を提案している. 加工システムにおいて, サーボ情報のみで工作 機械の強制／自励びびり振動のその場測定が可能なことを実証しており, 工学的, 工業的に価值が高く, 沼田記念論文賞 に值すると認められる。

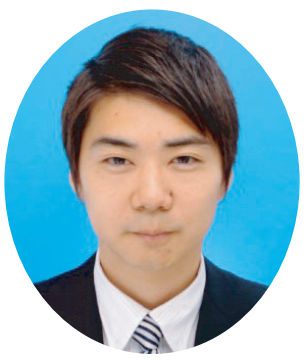

大 和 駿太郎

2018 年慶應義塾大学 大学院理工学研究科総 合デザイン工学専攻前 期博士課程修了。同専 攻後期博士課程。修士 (工学)

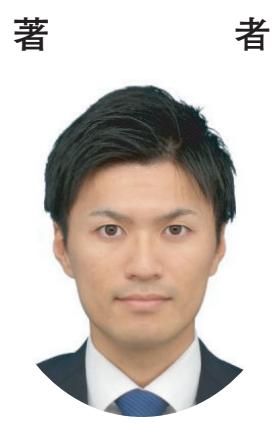

平野貴之

2016 年慶應義塾大学 大学院理工学研究科総 合デザイン工学専攻前 期博士課程修了。アビ ームコンサルティング 株式会社 $\mathrm{P} \& \mathrm{~T}$ Digital ビジネスユニ ット SCM セクター 修士 (工学)

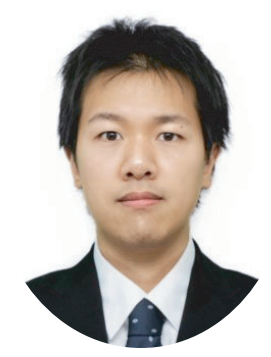

山田雄 基

2017 年慶應義塾大学 大学院理工学研究科総 合デザイン工学専攻後 期博士課程修了。日本 精工株式会社. 博士 (工学)

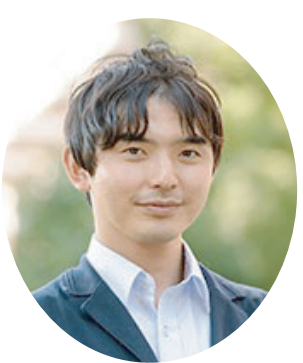

小池

綾

2016 年慶應義塾大学 大学院理工学研究科総 合デザイン工学専攻後 期博士課程修了慶應 義塾大学理工学部シス テムデザイン工学科助 教. 博士 (工学)

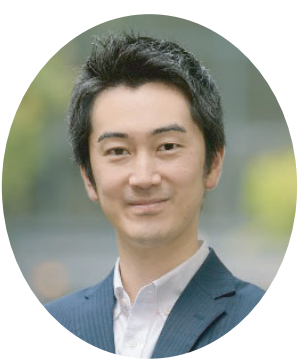

柿沼康弘

2006 年慶應義塾大学 大学院理工学研究科総 合デザイン工学専攻後 期博士課程修了. 慶應 義塾大学理工学部シス テムデザイン工学科准 教授. 博士（工学） 
Design and testing of a compact non-orthogonal two-axis Lloyd's mirror interferometer for fabrication of large-area two-dimensional scale gratings

Precision Engineering Vol. 52, pp. 138-151

大面積 2 次元エンコーダ用のグレーティング製作のため, ロイドミラー干渉計を応用した露光系を提案するとともに, シミュレーションによる光学系設計, グレーティング試作，性能評価までを一貫して行った完成度の高い論文である. 計 測分野の成果として工学的, 工業的に有用であり, 沼田記念論文賞にふさわしい論文と判断した.

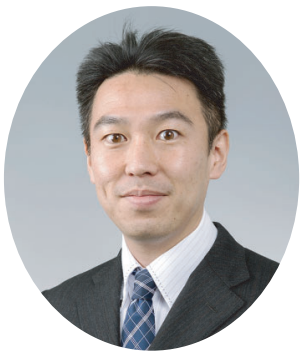

清 水 裕 樹

2009 年名古屋大学大 学院工学研究科機械理 工学専攻（社会人コー ス）修了. 東北大学大 学院工学研究科ファイ ンメカニクス専攻准教 授. 博士 (工学)

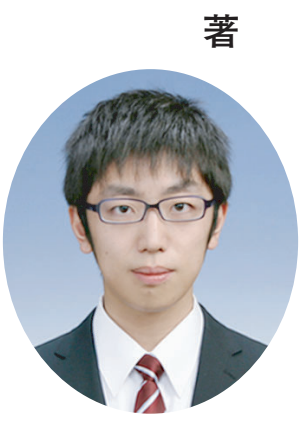

相 原 涼

2015 年東北大学大学 院工学研究科ナノメカ 二クス専攻修了。キヤ ノン株式会社。修士 (工学)

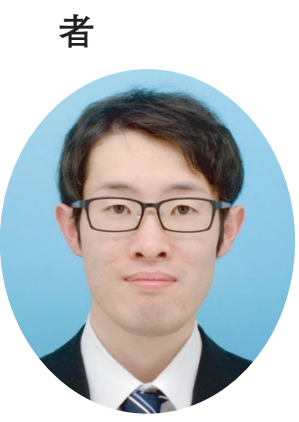

\section{真 野 和 樹}

2017 年東北大学工学 部機械・知能系ナノメ カニクスコース卒業。 東北大学大学院工学研 究科ファインメカニク 又専攻博士前期 2 年の 課程 2 年. 学士 (工 学)

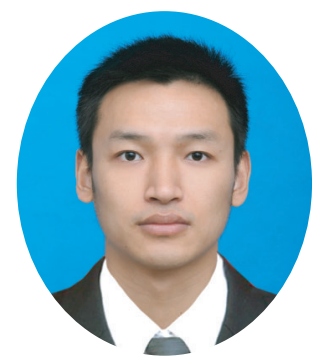

Chong Chen

2017 年中国湖南大学 修了. 東北大学大学院 工学研究科ファインメ カニクス専攻博士後期 3 年の課程 2 年. 修士 (工学)

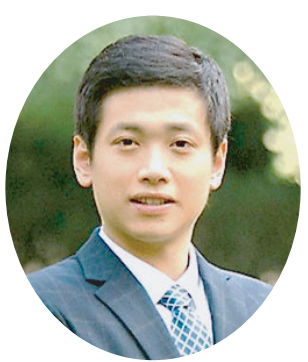

Yuan-Liu Chen

2014 年中国浙江大学 機械工学科修了。 Research Professor, School of Mechanical Engineering, Zhejiang University. 博 士（工 学)

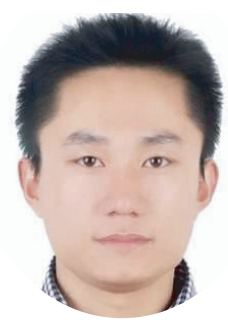

Xiuguo Chen

2013 年 Mechanical and Electronic Engineering, Huazhong University of Science and Technology. Assistant Professor, Huazhong University of Science and Technology. 博士 (工学)

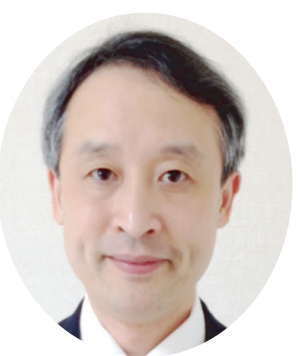

高

偉

1994 年東北大学大学 院工学研究科精密工学 専攻博士課程修了。東 北大学大学院工学研究 科ファインメカニクス 専攻教授. 博士 (工 学) 


\section{8 年度（第 21 回）精密工学会高城賞}

Super-Accurate Angular Encoder System with Multi-Detecting Heads Using VEDA Method

精密工学会誌 84 巻 8 号, pp. 717-723

本論文は，ロータリーエンコーダの高精度化のための自己校正するVEDA を提案するものである，これは，多点法の原 理を応用した周波数領域で処理するもので，実際の実験では 6 個のセンサで \pm 0.07 秒を達成している。本論文の成果は， 工業的有用性が高く, 精密工学の発展に寄与するものであり, 精密工学会高城賞にふさわしいと判断した。

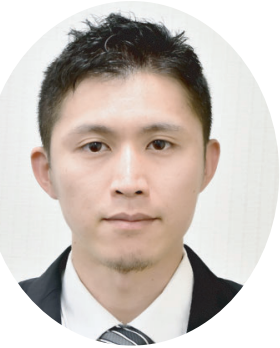

石 井信 行

2010 年東京工業大学 大学院理工学研究科物 性物理学専攻博士前期 課程修了。株式会社マ グネスケールレーザ スケール事業本部 LS 事業 2 部レーザスケー ル技術 2 課高精度回転 係 係長・上席研究 員. 慶應義塾大学大学 院理工学研究科博士課 程所属

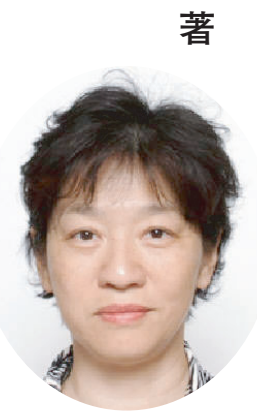

谷口 佳代子

1977 年横浜国立大学 教育学部物理学科卒 業. 同年, ソニー株式 会社中央研究所入社, ソニーママグネスケー 儿等を経て, 現在, 株 式会社マグネスケール 専務取締役 CTO

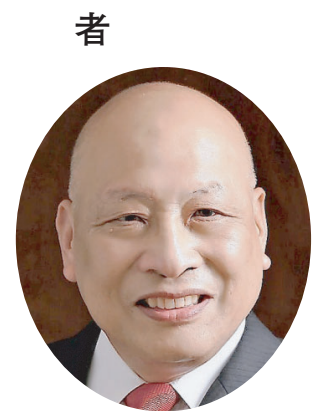

山 崎 和 雄

1975 年慶應義塾大学 大学院理工学研究科機 械工学専攻博士課程修 了。同年東京芝浦電気 株式会社入社, 1980 年豊橋技術科学大学生 産システム工学系専任 講師, 1990 年 7 月ょ り現在までカリフォル ニア大学デービス機械 航空工学科教授, 2011 年 1 月より現在までカ リフォルニア大学バー クレー機械工学科教授

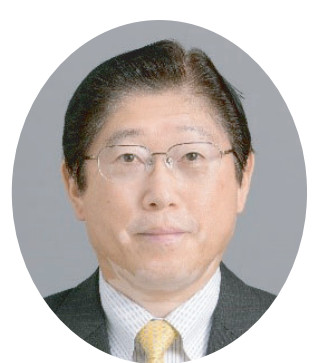

青 山 英 樹

1981 年 3 月室蘭工業 大学機械工学科卒業. 博士 (工学) (北海道 大学) 1992 年 3 月 ～ 1993 年 3 月カリフ オルニア大学研究員. 1994 年 4 月慶應義塾 大学理工学部専任講 師. 1996 年 4 月慶應 義塾大学理工学部助教 授. 2006 年 4 月慶應 義塾大学理工学部教 授. 
Chip control in turning with synchronization of spindle rotation and feed motion vibration

Precision Engineering Vol. 53, pp. 38-45

本論文は, 切削加工に低周波振動を援用することにより, 通常切削と比較して比切削抵抗が小さくなることを実験的に 明らかにしたものである。さらに加工条件を調整して切り屑形状を制御することにより，切削力と仕上面粗さを低減させ ることが可能であることを示した。この成果は工業的有用性が非常に高い上，発展性もあり，精密工学会高城賞にふさわ しいと判断した.

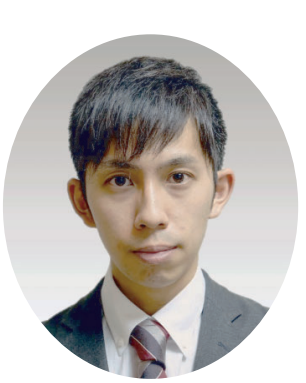

三宅章 仁

2018 年東京農工大学 大学院工学府機械シス テム工学専攻博士後期 課程単位修得満期退 学. 現在, 株式会社シ マ) 勤務。修士（工 学)

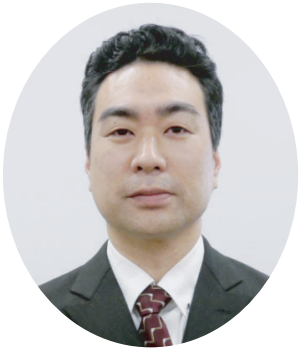

野

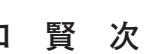

2000 年東京工業大学 総合理工学研究科精密 機械システム専攻修 了.シチズン時計株式 会社研究開発センター 開発部勤務。修士（工 学)

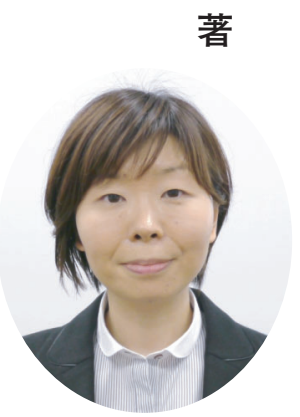

北風絢子

2008 年千葉大学自然 科学研究科機械システ 厶専攻修了。シチズン 時計株式会社研究開発 センター開発部勤務。 修士 (工学)

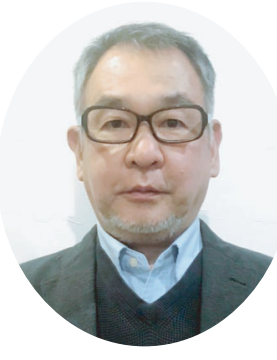

$$
\text { 三 宮 一 彦 }
$$

1985 年奈良県立生駒 高等学校卒業. シチズ ンマシナリー株式会社 開発本部開発企画部勤 務。

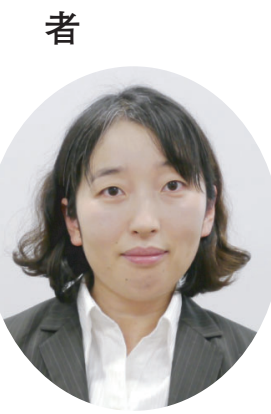

加 藤 聖 子

2009 年打茶の水女子 大学大学院人間文化創 成科学研究科理学専攻 修了。シチズン時計株 式会社研究開発セン夕 一開発部勤務。修士 (理学)

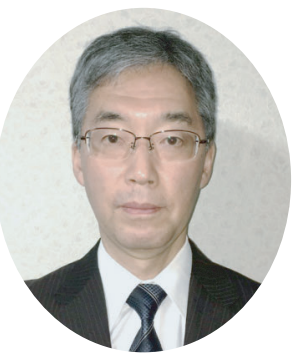

中 谷 尊 -

1984 年法政大学工学 部電気工学科電気電子 専攻卒業. シチズンマ シナリー株式会社開発 本部開発企画部勤務。 学士 (工学)

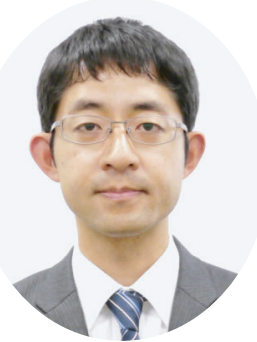

村 松 正 博

1999 年千葉大学工学 部機械工学科卒業. シ チズン時計株式会社研 究開発センター開発部 勤務. 学士 (工学)

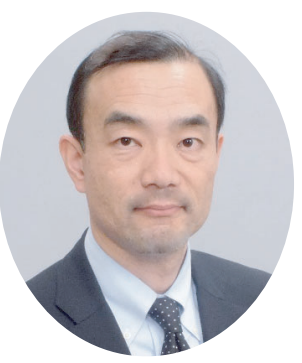

笹 原弘之

1988 年東京工業大学 工学部機械物理工学科 卒業. 東京農工大学工 学研究院先端機械シス テム部門教授. 博士 (工学) 


\section{8 年度（第 15 回）精密工学会研究奨励賞}

両面研磨加工におけるウェーハ厚さむら抑制の ための加工条件最適化

精密工学会誌 84 巻 3 号, pp. 277-283

福井克成, 廣瀬研二, 佐竹うらら, 榎本俊之, 杉原達哉

両面研磨加工における特異形状の発生および厚さむらの抑制 を目的に, ウェーハと研磨パッドおよびキャリアホール内壁間 の摩擦, ウェーハと研磨パッドの間の圧力分布などを考慮した 加工モデルを構築している。 そして, そのモデルを用いて最適 化した加工条件により, 特異形状の発生および厚さむらが大幅 に抑制されることを実験的に検証している。工学的および工業 的に価值の高い論文であり, 研究奨励賞にふさわしいと判断し た。

\section{受 賞 者}

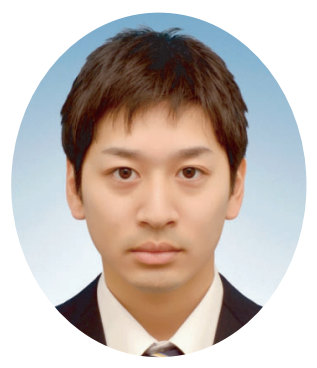

\section{福 井 克 成}

2018 年大阪大学大学院工学 研究科機械工学専攻修了. 株式会社デンソーテン。修 士 (工学)

A novel technique for slicing $\mathrm{SiC}$ ingots by EDM utilizing a running ultra-thin foil tool electrode

Precision Engineering Vol. 52, pp. 84-93

Yonghua Zhao, 國枝正典, 阿部耕三

$\mathrm{SiC}$ インゴットの放電加工切断用工具に薄フォイルを用いる ことを提案し, 適切な工具材料や放電加工条件など基本特性を 明らかにするとともに, 走査型のマルチ切断など高効率な切断 を実現するための加工システムを提案・実証した。これによ り, $\mathrm{SiC}$ インゴットの高精度かつ無駄の少ない切断法を実現し た。本成果は，産業分野において工業的有用性が高く精密工学 の発展に寄与するものであり, 研究奨励賞にふさわしいと判断 した。

\section{受 賞 者}

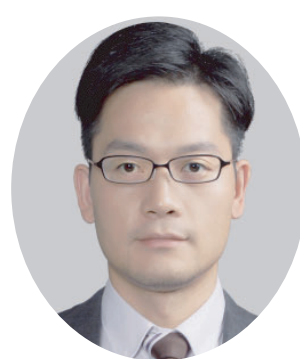

\section{Yonghua Zhao}

2005 年 7 月中国河南省済源 市第一高等学校卒業. 2009 年 7 月中国ハルビン工業大 学機電工程学院卒業. 2011 年 7 月中国ハルビン工業大 学機電工程学院修士課程修 了. 2011 年 9 月東京大学大 学院工学系研究科精密工学専攻博士課程入学. 2015 年 3 月東京大学大学院工学系研究科精密工学専攻博士課程修 了. 2015 年 4 月東京大学大学院工学系研究科精密工学専 攻助教. 2018 年 9 月中国南方科技大学機械とエネルギー 工程系助理教授. 現在に至る
多次元応答 PLS 回帰分析による近赤外物質判 別法の高速化

精密工学会誌 84 巻 12 号, pp. 1050-1058

村瀬王哉, 加藤邦人

本論文は, 近赤外画像を用いた物質判定の処理時間の高速化 を目的とし, 多クラス判別が可能なアルゴリズムを適用するこ とで, 人肌, 植物, アスファルトの判別に対して, 従来手法と ほぼ同等の精度を維持したまま，処理速度の大幅な短縮化が図 れることを実証している. 本提案手法は, 自動車運転支援シス テムの実用化につながる技術として期待でき, 学術的にも工業 的にも価值が高いと評価できる。よって, 研究奨励賞にふさわ しいと判断した.

\section{受 賞 者}

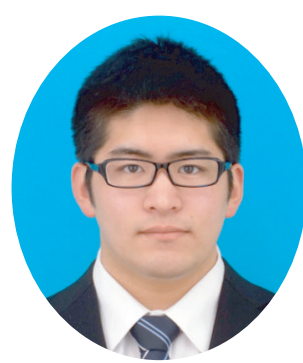

村 瀬 王 哉

2018 年岐阜大学工学部電気 電子・情報工学科卒業。岐 阜大学大学院自然科学技術 研究科知能理工学専攻修士 課程 1 年在学中. 学士（工 学)

Application of Hilbert-Huang transform for vibration signal analysis in end-milling

Precision Engineering Vol. 53, pp. 263-277

Agus Susanto, Chia-Hung Liu, 山田啓司, Yean-Ren Hwang, 田中隆太郎, 関谷克彦

本論文は加工時の振動波形を重力波干渉計の重力崩壊信号探 しに使われる Hilbert-Huang 変換で解析し, 従来技術（短時間 FFT, ウェーブレット）より加工状態の違いを鮮明に区別可能 なことを実証した。ソフトウエア技術なので，汎用性が高く， 工具磨耗や油ぎれの検出など, 応用研究の広がりを期待でき る. この成果は工学的.工業的な有用性が高く, 精密工学の進 展に大きく寄与するものと認められる。

\section{受 賞 者}

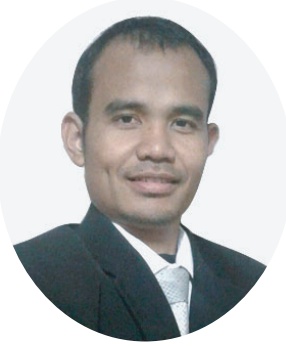

\section{Agus Susanto}

2011 年 8 月 Sepuluh Nopember Institute of Technology 修了. 2019 年 3 月広島大学大学院工学研究 科修了. State Polytechnic of Madiun, インドネシア講 師. 博士 (工学) 